\title{
フェムト秒レーザーピーニングによる炭素鋼の表面処理
}

\author{
津山 美穂 ${ }^{1}$, 柴柳 敏哉 ${ }^{2}$, 塚本 雅裕 ${ }^{2}$, 阿倍 信行 ${ }^{2}$, 中野 人志 ${ }^{1}$ \\ '近畿大学大学院 総合理工学研究科エレクトロニクス系工学専攻 († 577-8502 大阪府東大阪市小若江3-4-1) \\ ${ }^{2}$ 大阪大学 接合科学研究所 (广567-0047 大阪府茨木市美穂ヶ 丘11-1)
}

\section{Surface Treatment of Carbon Steel by Femtosecond Laser Peening}

\author{
Miho TSUYAMA, ${ }^{1}$ Toshiya SHIBAYANAGI, ${ }^{2}$ Masahiro TSUKAMOTO,${ }^{2}$ Nobuyuki ABE, ${ }^{2}$ and Hitoshi NAKANO ${ }^{1}$ \\ ${ }^{1}$ Program in Electronic Engineering, Interdisciplinary Graduate School of Science and Engineering, Kinki University, \\ 3-4-1 Kowakae, Higashi-osaka, Osaka 577-8502 \\ ${ }^{2}$ Joining and Welding Research Institute, Osaka University, 11-1 Mihogaoka, Ibaraki, Osaka 567-0047
}

(Received July 30, 2009)

\begin{abstract}
Femtosecond laser peening has been demonstrated in carbon steel. The sample used in this study, commercial S45C carbon steel annealed for various temperatures, was investigated under femtosecond laser-shock loading in plasma confined by water. Vicker's microhardness is used to probe work hardening due to the plastic deformation induced by laser peening. Our results indicate that the femtosecond laser has the potential to improve the mechanical performance of S45C carbon steel. The effects of laser peening depend on the laser irradiation parameters and the initial state of S45C adjusted by annealing temperature before laser irradiation. The optimum temperature of the heat treatment for laser peening has been estimated to be 600 degree through hardness measurements.
\end{abstract}

Key Words: Laser peening, Laser hardening, Femtosecond laser, Carbon steel, S45C

1.はじめに

レーザーピーニングは，レーザー誘起衝撃波によって 金属表面を冷間加工することにより，圧縮残留応力層や 硬化層を発生させる表面処理技術である ${ }^{1-3)}$ ：ショット ピーニングとの類似性からレーザーピーニングと呼ばれ ているが，欧米ではレーザー衝撃処理ということもあ る.

レーザーピーニングは金属疲労や応力腐食割れに対す る防止策として使用されている。 その対象は, 航空機部 品や原子力発電所などの高い信頼性が要求される部分で ある ${ }^{1,4)}$. ショットピーニングは無数の鉄あるいは非鉄 金属の球 (ショット)を高速度で金属表面に衝突させ，金 属の機械的性質を変化させる技術である ${ }^{5)}$ ，そのため, ショットピーニングを行った金属面は無数のくぼみで覆 われ，表面が粗くなる。また，ピーニング処理後に ショット材の回収作業が必要となる。

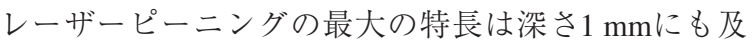
ぶ表面処理が可能なことにある。また，材質・形状・部 位に応じてパルスエネルギーなどの条件を制御すること が容易であり，ショットピーニングのようなショット材 の回収作業を必要としない。さらに, 非接触であり, ピーニング処理中の反力が生じない等の特長を備えてい る。そのため, 高い信頼性が要求される原子炉や航空機
部品などの処理に利用可能となる ${ }^{1,6)}$. 現在報告されて いるレーザーピーニングの研究はNd:YAGレーザーやガ ラスレーザーのナノ秒パルスを用いたものが多く, 種々 のレーザーパラメータ変化や対象試料の初期状態変化に 対するピーニング効果に関しては明確になっていない.

我々はレーザーピーニング用の光源として，フェムト 秒レーザーを検討している7)。 フェムト秒レーザーは， その高いピーク強度により，極めて大きな衝撃圧力を対 象試料に与えることができる ${ }^{8)}$ 。金属の塑性変形を端緒 とするレーザーピーニングにおいては，強い衝撃圧力の 発生は有利である。しかしながら，フェムト秒レーザー ピーニングの報告例は非常に少なく，低炭素鋼に対する 実験9) と我々が行ったステンレス鋼に対する実験7)が挙 げられるのみであり，いずれも系統的な研究はなされて いない.

本研究では，フェムト秒レーザーの各種パラメータを 変化させた際のレーザーピーニング効果について調べ た。試料としては一般建築物の骨格や橋梁などの大型構 造材に適用されるS45C亜共析炭素鋼 (以下S45C と略す) を用いた。また，S45Cの組織を変化させるために熱処 理を施し，レーザーピーニングに望ましい素材としての 条件をも同時に調べた。その際, 試料の塑性変形に起因 した硬度変化をレーザーピーニング効果の指標とした。 


\section{2. フェムト秒レーザーピーニング}

Fig. 1にレーザーピーニングの原理図を示す. 水中の 金属試料に対しパルスレーザーを集光照射すると, 試料 表面にアブレーションプラズマが発生する。発生したプ ラズマは，金属試料の周囲に存在する水の慣性により膨 張が抑制されるため, 数10 GPaにもおよぶ高い圧力状態 となる ${ }^{10,11)}$ 。この圧力により発生した衝撃波のエネル ギーが試料の降伏限界を超えると塑性変形が生じ, 試料 表面に圧縮残留応力層の形成や加工硬化が生じる ${ }^{1,12)}$.

レーザーピーニングによる塑性変形量は, 次式に示す ように, レーザーパルス幅とレーザー誘起圧力の積に比

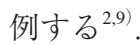

$$
L_{P} \propto \tau_{P} \cdot P
$$

ここで, $L_{P}$ は塑性変形量, $\tau_{P}$ はレーザーパルス幅, $P$ は レーザー誘起圧力である。尚，（1）式はナノ秒レーザー 照射において成立するものであり，フェムト秒レーザー 照射の場合には，レーザーパルス終了後にプラズマが発 生するため, $\tau_{P}$ ではなく衝撃波の継続時間に置き換えて 考えるのが妥当である. レーザーピーニング効果は試料 表面での力積の大きさで決定される．フェムト秒レー ザーはパルス幅が短く，発生する衝撃波の継続時間もナ ノ秒レーザーに比べて極めて短い ${ }^{8)}$. しかしながら, 先 にも述べたようにフェムト秒レーザー駆動衝撃圧は極め て大きく ${ }^{8)}, \tau_{P}$ の小ささを圧力 $P$ 小大きさで補うことが可 能である。また，フェムト秒レーザーの金属照射におい ては，プラズマがレーザーパルス終了後に発生するた め，レーザーとプラズマの相互作用がなく ${ }^{13,14) ， レ ー ~}$ ザーエネルギーは損失なしに試料表面に到達できると考 えられる。発生する衝撃波は定常衝撃波であり, ナノ秒 レーザー誘起衝撃波に比べて, 金属内部への効果的な伝 播を期待できる。

ところで, 塑性変形による材料の硬化現象 (加工硬化) は材料の結晶状態，転位密度や組織等に大きく依存す る。したがって, レーザーピーニング効果の総合評価に はレーザーパラメータのみならず，材料の初期状態の把 握が必要である。

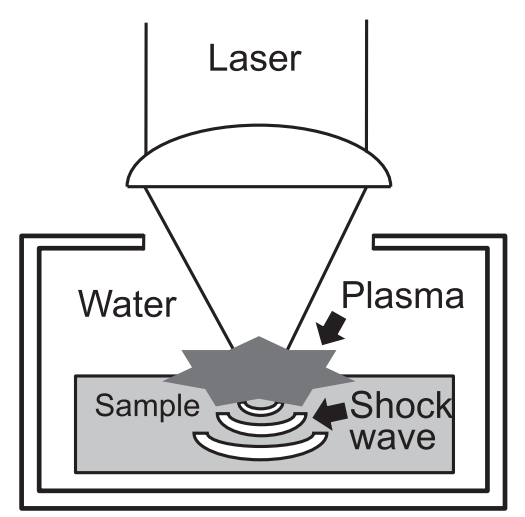

Fig. 1 Principle of laser peening.

\section{3. 実験方法}

本実験では波長 $800 \mathrm{~nm}$ のエムト秒レーザーを用い た.レーザー集光後のビームスポットは楕円形であり，

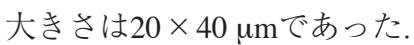

$\mathrm{S} 45 \mathrm{C}$ 等，市販の金属材料は圧延加工等が施されてお り，内部にひずみが蓄積している。また，ブロックに切 断した場合, 切断面近傍に残留応力が発生する。 そのた め, レーザー照射前試料の初期状態を実験毎に統一する ことが困難となる。すべての金属試料の初期状態を等し くさせるため, 試料をアニーリング(焼き鈍し)処理し た。 また, 残留応力・ひずみを除去した金属は加工硬化 が生じやすく，レーザーピーニング効果を見出しやす い.アニーリングには，加熱温度，保持時間がプログラ ム制御可能な真空電気炉を用いた。試料の大きさは $2 \mathrm{~cm} \times 2 \mathrm{~cm} \times 0.5 \mathrm{~cm}^{\mathrm{t}}$ とし，表面および側面をバフ研磨 仕上げした。レーザーピーニング実験においては，試料 表面に黒色ペイント等のレーザー吸収層をコーティング する場合が多いが, 佐野他らが開発した手法 ${ }^{1,6)}$ に従い, 吸収層を設けなかった。

$\mathrm{S} 45 \mathrm{C}$ の残留応力は, 約 $450{ }^{\circ} \mathrm{C}$ から除去され始め $600{ }^{\circ} \mathrm{C}$ で完全に除去されるとの報告がある ${ }^{15)}$ 。これに従い, ア ニーリング温度を, $200{ }^{\circ} \mathrm{C}$ か $\mathrm{A} 1$ 変態点 $\left(726^{\circ} \mathrm{C}\right)$ 以下の

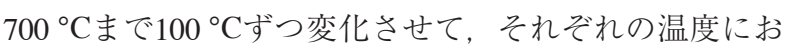
いて等温焼鈍を施し，レーザー照射用試料を作成した。 なお，保持時間は1時間で，炉冷した。

実験配置図をFig. 2に示す。ミラー，レンズ，ウェッ ジ基板を用いて，水中に置かれた金属試料にレーザー光 を集光照射できる光学配置となっている. 図中のCCD カメラはレーザーの集光状態を観測している。PiNダイ オードはパワーメータで校正されており，照射エネル ギーモニターとして利用されている。試料は水槽中に専 用ホルダーで固定されており，水槽はコンピュータ制御 可能な自動ステージに装着されている.

レーザーパラメータは以下のように設定した。 パルス 幅は230 fs一定とし，エネルギーフルエンスを3〜25 $\mathrm{J} / \mathrm{cm}^{2}$, カバレッジは100～ $500 \%$ と変化させた. カバ レッジ $F_{\mathrm{C}}$ は加工面積に対する加工痕面積の総和の比より 求められるものであり，次式で示される.

$$
F_{C}=\frac{\pi d^{2} N}{4 A} \times 100[\%]
$$

ここにdはレーザーの照射スポット径，Nは試料に照射

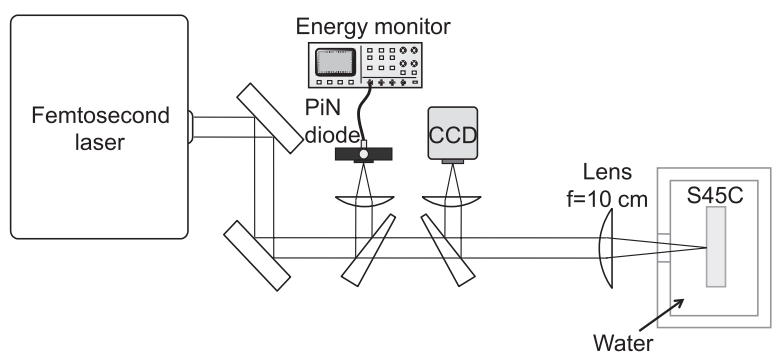

Fig. 2 Experimental arrangement for femtosecond laser shock peening of metal. 
したレーザーのパルス数，Aは照射を受けた面積であ る。仮に，すき間も重ね合わせもなく全面を1回レー ザー照射したとするとカバレッジは100％となる。レー ザー光は試料エッジから入射され, 試料中央に向かっ て, 設定されたカバレッジで2次元照射される。照射面 積(式(2)のA)は $2 \mathrm{~mm} \times 2 \mathrm{~mm}$ とした。また，ピーニング 処理を適当な時間内で終了させるため, レーザーの繰り 返し周波数を $100 \mathrm{~Hz}$ に設定した。

レーザーピーニングによる塑性変形に起因した加工硬 化を調べるため，ビッカース硬度計を用いて金属表面お よび側面の硬度を測定した。試料の梁さ方向硬度分布 は，試料側面の硬度測定により，推定することにした。 レーザーは試料エッジから照射されているため, 試料表 面で生じた塑性変形の影響が側面にも現れる。

レーザー照射後試料には，断面を見出す切り出し加工 等, 一切の機械的加工を行わなかった. したがって, 硬 度測定においては，レーザーピーニングによる加工硬化 のみに着目可能となっている。レーザー照射試料の硬度 からレーザー未照射試料の硬度を引いた值を硬度上昇量 $(\Delta \mathrm{HV})$ と定め, アニーリング温度ごとの硬度上昇量の 異なりを調べた。

\section{4. 実験結果および考察}

アニーリング後のS45C硬度測定結果をFig. 3に示す。 同一試料の硬度を10回測定した際の平均值に対する標準 偏差は3〜6\%であった。そのため, 本実験においての 硬度測定回数は各試料 2 力所とし, その平均值を測定結

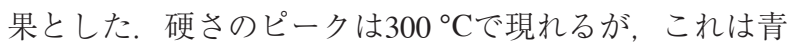
熱脆性によるものである。アニーリング温度の上昇に よって残留応力が除去される結果として, 硬度低下を生 じていることが判る。レーザーピーニング実験において は，Fig. 3に示した各硬度を初期硬度とし，各アニーリ ング材におけるピーニングによる硬さ変化を評価した。

カバレッジ100％一定とし，エネルギーフルエンスを 3〜 $25 \mathrm{~J} / \mathrm{cm}^{2}$ に変化させた時の試料深さ方向硬度分布を Fig. 4に示す. 図の横軸は試料表面からの深さ, 縦軸は ビッカース硬度を示している。眓中の破線はアニーリン グ温度 $700{ }^{\circ} \mathrm{C}$ における初期硬度を示している。 すべての

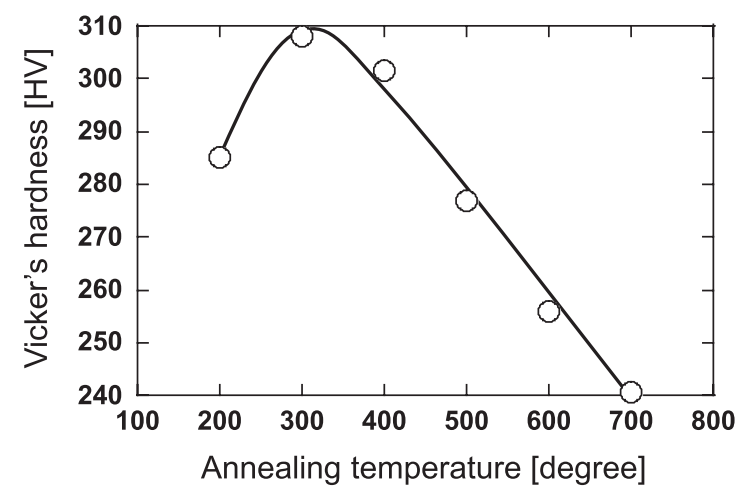

Fig. 3 Hardness of S45C as a function of annealing temperature before laser irradiation.

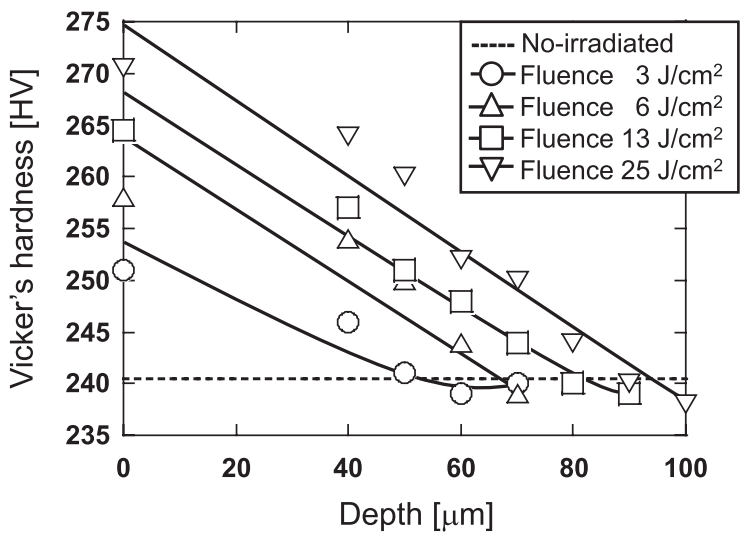

Fig. 4 Vicker's microhardness as a function of the depth from surface for various energy fluences.

エネルギーフルエンスにおいてS45Cの硬度上昇が見ら れており，フェムト秒レーザー誘起衝撃波によって塑性 変形が生じたものと考えられる。衝撃波の継続時間の短 さを大きな駆動圧力が補った結果と考えられ，フェムト 秒レーザーはレーザーピーニング用の光源としての能力 を十分に持つと言える. Fig. 4は, エネルギーフルエン スが大きいほど材料深くまで硬化が進む特性を示してい る。衝撃圧力はレーザーエネルギーの関数であり，エネ ルギーの大きさが単純にピーニング効果に寄与したもの と解釈している.

Fig. 5はアニーリング温度ごとの硬度上昇量 $(\Delta \mathrm{HV})$ を, 種々のエネルギーフルエンスでの照射において測定した 結果である. 同じレーザーパラメータであるにもかかわ らず，アニーリング温度ごとに硬度上昇量が異なってい ることがわかる。青熱脆性が生じた $300{ }^{\circ} \mathrm{C}$ 付近は硬度上 昇が最も低い，青熱脆性は炭素が転位を固着して，転位 の運動抵抗を高めることが主因である。アニーリングに より転位密度を減ずることができず, 結果としてピーニ ングによる硬度上昇が少ないと考えられる。硬度上昇は

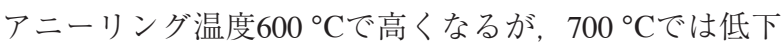
している.

次に，エネルギーフルエンスを $5.9 \mathrm{~J} / \mathrm{cm}^{2}$ 一定とし，カ バレッジを100～500\%と変化させた時の深さ方向硬度 分布をFig. 6に，アニーリング温度ごとの硬度上昇量を Fig. 7に示す. Fig. 6中の破線はアニーリング温度 $600{ }^{\circ} \mathrm{C}$

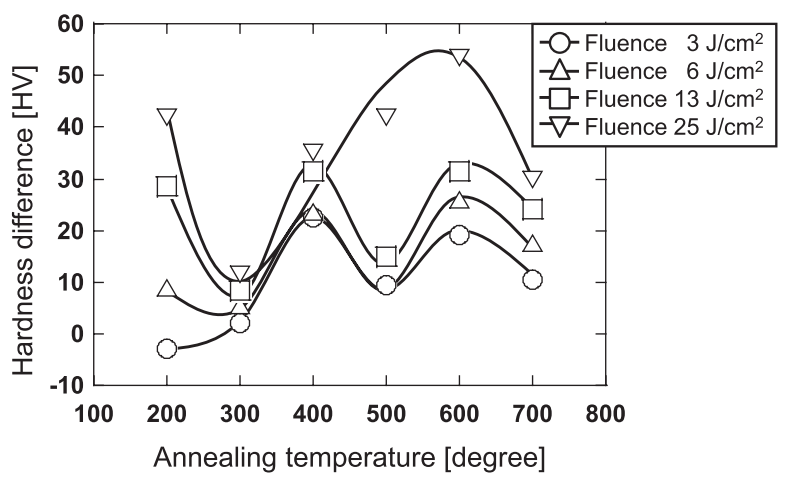

Fig. 5 Relation between hardness difference and annealing temperature for various energy fluences. 


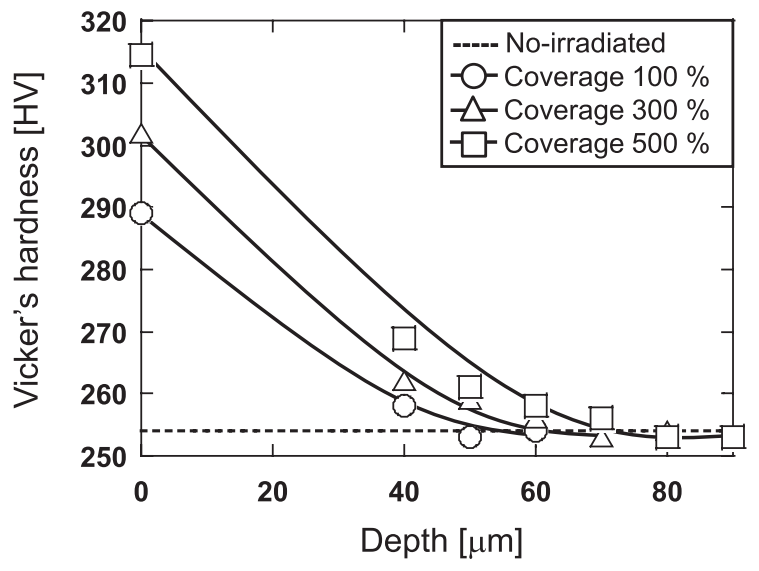

Fig. 6 Vicker's microhardness as a function of the depth from surface for various coverages.

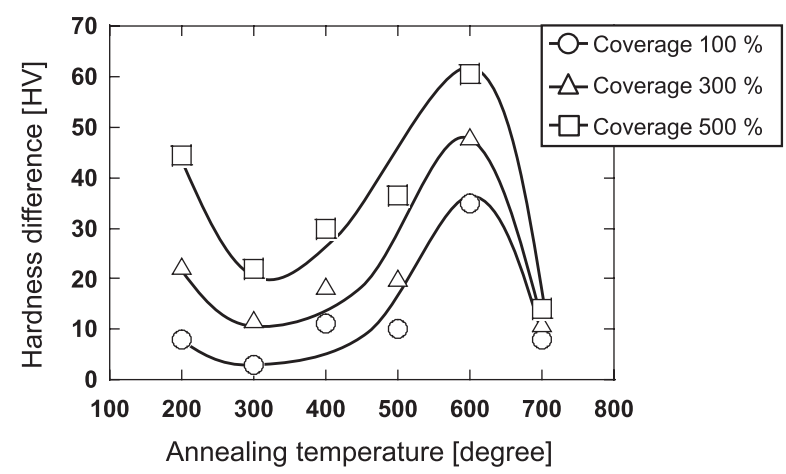

Fig. 7 Relation between hardness difference and annealing temperature for various coverages.

における初期硬度を示している。 Fig. 6より，カバレッ ジが大きいほど硬化していることがわかる。 カバレッジ は単位面積当たりのレーザー照射回数を示す指標であ り, ピーニング効果向上のためには多数回のレーザー照 射が有効であることがわかる。

Fig. 7は, Fig. 5と同様に，アニーリング温度ごとに硬 度上昇量が異なる結果となっている。硬度上昇量は

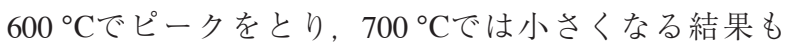
Fig. 5 と同様である。したがってS45C炭素鋼の場合, $600{ }^{\circ} \mathrm{C}$ でアニーリング処理すれば，多様なレーザーパラ メータに対して最適なピーニング結果が得られる.

金属の初期状態によってピーニングの効果は異なるこ とが示された。その理由は金属の結晶構造にあると考え られる。一般に，加工硬化によって大量の転位(ひずみ) が導入されて原子配列が乱れた状態の金属を加熱する と, 点欠陥や転位などの格子欠陥が消滅してひずみが減 少する，さらに長時間あるいは高温で加熱すると，ひず みのない新しい結晶粒が生成する再結晶現象が起こる. さらに，加熱を続けると結晶粒が成長して結晶粒組織が 粗大化する。結晶粒が大きいほど金属は軟らかくなり, 再び加工硬化能を回復する。すなわち, 加工硬化した金 属はアニーリングにより硬度が加工硬化前の状態に戻 り, 加工硬化が起こりやすくなる．S45Cの場合，ア ニーリング温度 $600^{\circ} \mathrm{C}$ ときには再結晶組織となるた
め, 硬度上昇量が大きくなったと考えられる。一方で, $700{ }^{\circ} \mathrm{C}$ において硬度上昇量が小さい原因は, パーライト 組織の影響によるものと推測している.

炭素鋼をオーステナイト温度域 (A1点以上A3点以下) で加熱してから徐冷すると, 初析フェライトに続いて A1点において共析反応によりフェライトとセメンタイ トが層状になって共存するパーライト組織が生成す る ${ }^{15)}$ 。 パーライト組織の存在は, 転位の運動抵抗となる 等, 本研究で着目している加工硬化現象に影響を与え

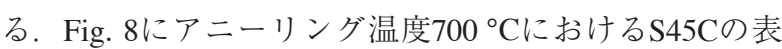
面組織を示す。試料を鏡面研磨し, ナイタル (3\%硝酸, $97 \%$ エチルアルコール)を用いてエッチングした後の光 学顕微鏡写真である。Fig. 8 (a) は低倍率での観測結果 であり，20〜30 $\mu \mathrm{m}$ 程度の結晶粒組織であることが判 る. Fig. 8 (b) は高倍率観測である。丸で囲んだ部分が パーライト組織であり，パーライト組織に特徵的な縞状

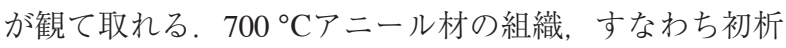
フェライトとパーライトの混合状態あるいはそれぞれの 相の大きさなどが $600{ }^{\circ} \mathrm{C}$ 以下のアニール材とは異なるこ とが本研究で得られたピーニングによる硬度上昇挙動の 違いの本質的な原因と考えている。 その解明にはより詳 細な組織解析が必要で, 今後の課題として残る。初析 フェライトとパーライトの量比は炭素の合金量に比例し て変化するので, S30C, S50C等のほかの炭素鋼におい ての結果は異なったものになると思われる。

アニーリング温度を上げるに連れて試料の初期硬度は 低下するが，軟らかいほど高いピーニング効果が得られ るわけではなく，最適な熱処理の条件が存在する. $\mathrm{S} 45 \mathrm{C}$ の場合, $600{ }^{\circ} \mathrm{C}$ 付近が最適であることが判明した が, 他の金属材料についても同様の調査が必要であると 考えている.

\section{5. 結 論}

本研究では，炭素鋼に対するフェムト秒レーザーピー ニング効果を硬度測定により明らかにするとともに, レーザー照射条件や材料の初期状態との関係を調べた。

得られた結果は以下の通りである.

・フェムト秒レーザーピーニング処理を行った炭素鋼の

ビッカース硬度は, レーザー未照射の試料に比べて向 上する。したがって，フェムト秒レーザーはレーザー ピーニング用の光源として十分な能力を持つ.

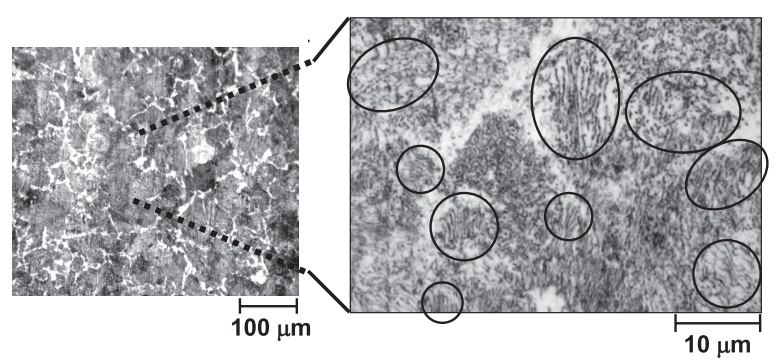

Fig. 8 Surface morphology of S45C annealed at 700 degree for (a) whole view and (b) expanded view. 
・照射フルエンスおよびカバレッジが高いほど硬度上昇 は大きく, より梁くまで硬化する.

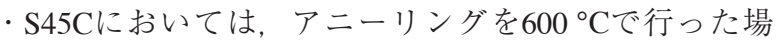
合のピーニング効果が最も大きい.

\section{参考文献}

1）佐野雄二, 依田 正樹, 向井成彦, 小畑稔 : レーザー研究 26 (1998) 793.

2) R. Fabbro, P. Peyre, L. Berthe, and X. Scherpereel: J. Laser Applications 10 (1998) 265.

3) P. Peyre and R. Febbro: Opt. Quantum Electron. 27 (1995) 1213.

4) D. W. See, J. L. Dulaney, A. H. Clauer, R. D. Tena glia: Surface Eng. 18 (2002) 32.

5）ショットピーニング技術協会：ショットピーニングの方法 と効果 (日刊工業新聞社, 1997) p.1.

6）佐野雄二, 依田正樹, 向井成彦, 小畑稔, 菅野眞紀,
嶋 誠之：日本原子力学会誌 42 (2000) 567.

7) H. Nakano, S. Miyauti, N. Butani, T. Shibayanagi, M. Tsukamoto, and N. Abe: J. Laser Micro/Nanoengi 4 (2009) 35.

8) T. Sano, H. Mori, E. Ohmura, and I. Miyamoto: Appl. Phys. lett. 83 (2003) 3498

9) D. K. Lee and E. K. Ashibn Jr: Proc. ICALEO (2008) 125.

10) Y. Sano, N. Mukai, K. Okazaki, and M. Obata: Nucl. Instrum. B 121 (1997) 432.

11) R. Fabbro, J. Fournier, P. Ballard, D. Devaux, and J. Virmont: J. Appl. Phys. 68 (1990) 775.

12）熟坂 芳弘, 神谷 眞好, 松田稔, 太田幸宏：日本塑性加工 学会誌 塑性と加工 49 (2008) 1091.

13）平尾一之, 邱建栄：フェムト秒テクノロジー - 基礎と応 用 ((株) 化学同人, 2006) p.5.

14) 電気学会編：レーザーアブレーションとその応用(コロナ 社, 1999) p.60

15）矢島鋭次郎, 市川理衛, 古沢浩一, 宮崎亨, 小坂井 孝生，西野洋一：若い技術者のための機械・金属材料 第 2版（丸善株式会社, 2007) p.103. 